\title{
THE VALUE OF ARCHAEOLOGY
}

Joanna Brück

University of Bristol

Department of Archaeology and Anthropology

43 Woodland Road, Bristol BS8 1UU, United Kingdom

joanna.bruck@bristol.ac.uk

I very much welcome the opportunity to comment on Gavin Lucas's keynote discussion, for it raises a number of interesting and timely issues. It is as a result of disciplinary insecurities as well as of particular ways of categorising academic practice that archaeologists continue to debate the pitfalls of "borrowing" theories from other disciplines. But to what extent should we see these as borrowed rather than shared? Although writers such as Hägerstrand or Wallerstein may have been more firmly embedded in other disciplines in their lifetimes (or have been claimed more vociferously by those fields after their deaths), their theories derive as much from ways of understanding the world common within their broader cultural contexts (the zeitgeist, as it were) as from unique disciplinary histories. Theories, whatever their disciplinary origin, derive their "popularity" from their fit with or ability to respond to the acute social and political concerns of the day. This is the case both for "lower order" travelling concepts such as agency and for "higher order" theories such as evolutionism. For this reason, Lucas is quite right to pick apart the perceived distinction between theory building and theory borrowing. The logico-deductive framework in which the pursuit of theory building took place in processual archaeology saw the process as neutral and objective: theories were viewed 
as value-free - scientific principles to be tested. But if we accept that theoretical frameworks are inevitably the product of particular social and political conditions, then "building" theory is neither better than nor different to "borrowing" it.

This, of course, requires us to question the difference between "topdown" and "bottom-up" theory. The distinction between these is something that Lucas explores in detail and, like him, I can see both benefits and problems with retaining this distinction. On the one hand, it is tempting to eschew the universalizing and autocratic claims of top-down approaches and to take a perspective that promises not just to democratize theory but to respond to the specificities of archaeological data - answering archaeological questions "at the trowel's edge", as Hodder (1999:92) puts it. On the other hand, it is surely the case that, whether sitting in a library or digging in a trench, our understanding of how the world works - from soil colour to social relationships - is a product of our own cultural traditions and contemporary politics. The idea that top-down theory is disconnected from the "realities" of lived experience and that a bottom-up approach allows a more authentic engagement with the past seems reasonable in some ways, but is in other ways problematic. Perspectives that argue that we should use the empirical evidence to develop new theories implicitly assume that our aim as archaeologists is to uncover the past, when it seems to me that the whole point of the discipline is to provide us with ways of thinking through troublesome issues in the present - whether those are climatic change, temporality, or gendered identity. In this sense, then, as Lucas points out, all archaeologists "do" theory, regardless of the character of their professional practice. The idea that the data itself should lead the way is appealing, but it is surely the case that we would not excavate, analyse or perhaps even recognize that data unless it in some way highlighted contemporary cultural needs: theory cannot magically emerge from the data nor, as Lucas rightly argues, should it be separated from practice. Even those identified as theoreticians base their theories on lived experience and - albeit often implicitly - are always working with particular datasets in mind. As such, the distinction between top-down and bottom-up theory is, I think, ultimately unhelpful, for both fulfil the same social function.

These points remind us that the creation of boundaries between academic disciplines is equally a matter of politics and can be linked to contemporary Western ways of categorizing the world (particularly dualisms such as nature-culture, or animate-inanimate). Of course, fields such as archaeology, anthropology, biology and geology can all be viewed as products of the colonialist and nationalist agendas of the 
eighteenth and nineteenth centuries - the assumption that any one of these is more "objective" than another is problematic. As such, although theoreticians may be claimed by particular disciplines, the boundaries of those subjects are open to deconstruction. Certainly, it is widely recognized that the conceptual categories underpinning the systems of value that differentiate academic fields such as history and archaeology (theory-practice; mind-body) are a product of post-Enlightenment rationalism, yet that has not boosted our own confidence in the discipline. Unfortunately, although Lucas suggests that borrowing scientific methodologies is usually considered less problematic than borrowing theories, that is not always the case: archaeologists (even those who work with ancient DNA or isotopes) are rarely seen as "real" scientists, but as practitioners of applied science who do not themselves develop new scientific theories or methods. Here, too, disciplinary hierarchies are at work. Yet, as Lucas discusses, the frequency with which "archaeology" or "excavation" are employed as concept metaphors in other disciplines speaks of their cultural potency. Although archaeology is often "reduced" to its methodologies (notably by the media), those methodologies themselves are powerful conceptual tools; this is hardly a surprise for, as Lucas points out, practices such as excavation, stratigraphic recording and landscape survey not only reflect the peculiar obsessions of modernity (such as linear concepts of time), but help to constitute that modern world, for example by normalizing the technologies of temporal and spatial measurement that underpin capitalism and colonialism. Our methodologies are therefore inescapably theoretical for they are built on particular ways of understanding the world.

This point allows us to return to questions regarding the character and purpose of archaeology. I agree with Lucas that re-valuing the practice of archaeology - the embodied engagement with pit edge or sherd that allows archaeologists to work through their place in the world - is crucial. Indeed, it is surely this that is the proper subject of archaeology: the fluid interface, the push and pull, between people and things both in the past and the present. Exploring those boundaries by working with - and sometimes against - the materiality of the archaeological record constitutes archaeologists' particular contribution, and it is one we should not be ashamed of, for it allows us to address concerns shared by other disciplines, from the impact of environmental degradation to changing concepts of personhood. Just as archaeology is an amalgam of approaches and perspectives drawn both from other fields of enquiry and from our wider cultural context (a point that can indeed be made for any academic discipline), so too this gives us an opportunity to comment on and contribute to debates that might not traditionally be viewed 
as "archaeological". Importantly, this means that archaeology can be both a particularizing and a generalizing subject, for just as we make broad assumptions about the properties of things, or the processes by which people and objects together create social networks, so too archaeological studies of the different ways in which those properties and relationships have been articulated in particular historical contexts help us understand the diversity of human experience.

Of course, if we contest the problematic split between theory and practice, there is less reason to be alarmed by the oft-perceived lack of theoretical innovation since the development of post-processual archaeology. As Lucas points out, the search for the "next big thing" in archaeological theory is driven by the modern Western obsession with "big men", grand narratives, innovation and competition. Contemporary archaeology's postmodern acceptance of a plurality of overlapping positions that cannot easily be equated with particular "isms" is often seen in negative terms but it is not clear to me that it should be. Origin myths evoking unilinear evolution and paradigm shifts are necessary only if we conceptualize archaeology as a discipline that can (or should) "advance" or "improve" over time, for example by providing increasingly accurate reconstructions of a "true" past; the assumption that this is the core purpose of archaeology has of course long been questioned. Just as disciplinary boundaries are often unhelpful (and may be as much to do with academic identity politics as with susbstantive differences in method, theory or subject matter), so the partisan promotion of theoretical divides within archaeology may ultimately be less constructive than collaboration and diversity of approach. For this reason, too, we must get over our love-hate relationship with archaeological theory. The antagonism towards theory still evident in many circles is not warranted, for every time we clean a section or examine a fragment of bone, we are engaging with ideas about how the world works and what human life means - albeit at a variety of temporal and spatial scales. As Lucas so eloquently argues, we must have confidence in ourselves, in our discipline, and in our ability to make a productive contribution to those broader "theoretical" debates.

\section{REFERENCE}

\section{Literature}

Hodder, I. 1999. The Archaeological Process: An Introduction. Oxford: Blackwell. 